\title{
KAJIAN STRATEGI DAN PROGRAM PERBAIKAN OPERASIONALISASI DARI MILK DISTRICT MODEL NESTLÉ DI JAWA TIMUR
}

\section{STUDY ON THE IMPROVEMENT STRATEGY AND PROGRAM FOR THE OPERATIONALIZATION OF NESTLE'S MILK DISTRICT MODEL IN EAST JAVA}

\author{
Bambang Ali Nugroho* \\ Program Studi Sosial Ekonomi, Fakultas Peternakan, Universitas Brawijaya, Jl. Veteran 161, Malang, 51611
}

\begin{abstract}
INTISARI
Penelitian ini bertujuan untuk mengeksplorasi pengembangan milk district model Nestle di Jawa Timur. Data sekunder tentang perkembangan persusuan di Jawa Timur digunakan untuk menganalisa faktor internal dan eksternal. Metode analisa SWOT digunakan untuk mengevaluasi kondisi perkembangan persusuan di Jawa Timur saat ini dan digunakan untuk membuat rekomendasi strategi untuk mengembangkan milk district model. Dalam pengertian sederhana, komponen dari milk district model Nestle meliputi: a) melakukan kesepakatan dengan peternak untuk melakukan pengumpulan susu segar dua kali setiap hari, b) membangun chilling centers dan collection points di desa, c) melakukan pengaturan transport susu segar dari collection centers ke industri pengolahan susu (IPS), dan d) mengimplementasikan program perbaikan kualitas susu segar. Pada realitanya membangun milk district model bukan merupakan core business atau core competence dari Nestle, akan tetapi mutlak dibutuhkan perintisan untuk membangunnya. Setelah dilakukan upaya perintisan maka pada perkembangan selanjutnya para peternak akan mampu mengorganisir diri mereka sendiri untuk memproduksi susu segar. Sekali pihak Nestle mengembangkan kapasitas para peternak lokal, maka keterampilan mereka akan dipergunakan seterusnya untuk mengembangkan usaha sapi perah. Nestle telah mencoba untuk mengintroduksikan berbagai jenis sistem insentif untuk menunjang upaya pengembangan kapasitas para peternak untuk menjamin agar mereka memiliki tanggung jawab pribadi (self responsibility) dalam proses budidaya sapi perah. Kegiatan proses budidaya sapi perah harus secara nyata memberikan dampak yang positif terhadap peningkatan produktivitas, kualitas produk, serta aspek keamanan produk, yang kesemuanya akan memberikan manfaat bagi Nestle.
\end{abstract}

(Kata kunci: Milk district model, Peternak, Koperasi, Industri pengolahan susu, Strategi, Program)

\begin{abstract}
The objective of this study was to explore the improvement of Nestle milk district model in East Java. Secondary data on dairy development in East Java was used to analyse internal and external factors. SWOT analysis method was used to evaluate existing condition of dairy development in East Java and to build a recomended strategy to improve milk district model. In simplest terms, setting up a milk district involved: a) negotiating agreements with farmers for twice-daily collection of their milk, b) installing chilling centers in the larger community and collection points in the villages or adapting existing collection infrastructure, c) arranging transportation from collection centers to the district's factory, and d) implementing a program to improve milk quality. In reality building a milk district model is not core business or core competence of Nestle but its something absolutely necessary to be introduced. After this program have been introduced, the smallscale dairy farmers were capable to organise themselves to produce freshmilk. Nestle have introduced various insentive systems to support smallscale dairy farmers capacity to guarantee that they have self responsability in dairy farming activities have positive impacts on productivity, quality product and product safety, that all that aspects will give benefit to Nestle.
\end{abstract}

(Key words: Milk district model, Dairy farmer, Dairy cooperative, Milk processing industry, Strategy, Program)

\footnotetext{
* Korespondensi (corresponding author):

Telp. +62811369216

E-mail: bamalnug@yahoo.com
} 


\section{Pendahuluan}

Usaha sapi perah di Jawa Timur telah berkembang sebagai usaha keluarga sejak masa penjajahan, dengan mendatangkan sapi perah $\mathrm{FH}$ dari Belanda. Kemudian pada tahun 1970, usaha sapi perah berkembang menjadi usaha swasta skala menengah, tetapi hanya terdapat secara terbatas pada wilayah-wilayah tertentu. Pada tahun 1978, pemerintah melakukan gerakan perkembangan usaha sapi perah, yang diawali dengan kebijakan penanaman modal asing (PMA) dalam bentuk industri pengolahan susu (IPS), sedangkan budidaya sapi perah tertutup bagi modal asing. Selanjutnya, pada tahun 1980, pemerintah menerbitkan Surat Keputusan Bersama (SKB) tiga menteri yang mengatur bahwa kegiatan usaha sapi perah merupakan usaha rakyat dan dikembangkan melalui koperasi serta koperasi mewakili peternak dalam kerjasama pemasaran susu dengan IPS.

Empat pelaku utama industri sapi perah dalam dua dekade terakhir ini adalah industri pengolahan susu, koperasi susu, peternak rakyat dan perusahaan sapi perah swasta yakni skala menengah dan skala besar. Masing-masing pelaku ini telah memberikan sumbangan yang berarti bagi produksi susu segar dan susu olahan bagi masyarakat, namun beban masyarakat masih lebih besar dibandingkan keuntungan yang diperoleh. Para ahli menilai bahwa peran pemerintah selama ini melalui berbagai regulasi menjadi sebab pertumbuhan produksi menjadi lambat, terjadi perkembangan bentuk pasar oligopoli dan teknologi yang statis serta melestarikan budidaya yang tidak efisien.

Produksi susu di wilayah Jawa Timur saat ini mencapai sekitar 600 ton per hari. Dari jumlah itu 410 ton dipasarkan ke PT Nestle, 40 ton ke PT Imdi di Pandaan, 21 ton ke Industri Pengolah Susu di Jakarta, 10 ton ke GKSI Jawa Tengah, 30 ton ke PT Greenfield, dan sisanya sekitar 9 ton per hari diproses sendiri oleh koperasi melalui Pusat Koperasi Industri Susu (PKIS) Sekar Tanjung yang merupakan gabungan enam koperasi primer di Jawa Timur. Jumlah itu dihasilkan oleh sekitar 130 ribu ekor sapi.

Kondisi pada tahun 2007, PT Nestle masih kekurangan pasokan sekitar 140 ton setiap harinya. Sedangkan PT Imdi kekurangan pasokan sekitar 10 ton, PT Greenfield Malang kekurangan pasokan sekitar 20 ton, dan PKIS Sekar Tanjung Pasuruan kekurangan pasokan sekitar 30 ton. Secara keseluruhan, permintaan susu mencapai 725 ton per hari. Adapun harga rerata susu per liter sekitar Rp. 2.200,00 sampai dengan Rp. 3.300,00.

Pada realitanya membangun milk district model bukan merupakan core business atau core competence dari Nestle, akan tetapi mutlak dibutuh- kan perintisan untuk membangunnya. Kemudian, setelah dilakukan upaya perintisan maka pada perkembangan selanjutnya para peternak akan mampu mengorganisir diri mereka sendiri untuk memproduksi susu segar. Sekali pihak Nestle mengembangkan kapasitas para peternak lokal, maka ketrampilan mereka akan dipergunakan seterusnya untuk mengembangkan usaha sapi perah. Nestle telah mencoba untuk mengintroduksikan berbagai jenis sistem insentif untuk menunjang upaya pengembangan kapasitas para peternak untuk menjamin agar mereka memiliki tanggung jawab pribadi (self responsibility) dalam proses budidaya sapi perah. Kegiatan proses budidaya sapi perah harus secara nyata memberikan dampak yang positif terhadap peningkatan produktivitas, kualitas produk, serta aspek keamanan produk, yang kesemuanya akan memberikan manfaat bagi Nestle.

Di masa mendatang, permintaan akan produk susu di wilayah Asia Tenggara diproyeksikan akan tumbuh sekitar 5\%, Afrika sekitar 6\%, China sekitar $14 \%$ atau dua kali lipat dari pertumbuhan rerata dunia. Mendasarkan pada angka proyeksi pertumbuhan permintaan tersebut maka Nestle dan IPS lainnya akan melakukan peningkatan kapasitas produksinya. Fenomena yang ada menunjukkan bahwa di berbagai pasar di wilayah tertentu terdapat pergeseran dimana susu UHT menggantikan susu segar, dengan pertimbangan susu UHT lebih tahan untuk disimpan. Selanjutnya, di wilayah lain produk berupa susu segar yang bersifat ready to drink masih dominan di pasar. Pengalaman di China menunjukkan bahwa perpindahan pola konsumsi ke susu segar mensyaratkan adanya fasilitas pendingin, baik untuk transport maupun storage. Hal itu disebabkan karena jauhnya lokasi produsen dengan konsumen, sebagai dampaknya pertumbuhan angka penjualan pabrik pengepakan susu segar secara tidak langsung dibayar oleh produsen susu segar/peternak, akibatnya tingkat keuntungan yang semestinya diperoleh produsen susu segar, sebagian besar dipergunakan untuk membiayai ongkos distribusi produk susu segar.

Dipandang dari sisi permintaan (demand side), jelas bahwa prospek industri pengolahan susu segar sangat cerah. Akan tetapi untuk mengantisipasi hal tersebut tidaklah mudah, oleh karena itu untuk meningkatkan produksi susu segar mutlak dibutuhkan ketersediaan induk dan dara untuk replacement, faktor ini merupakan faktor yang paling krusial. Hal itu disebabkan karena untuk merealisasikan adanya ketersediaan induk dan dara dibutuhkan biaya yang relatif besar, dan adanya kecenderungan biayanya semakin meningkat seiring dengan adanya peningkatan harga susu segar. Kondisi tersebut menyebabkan kemampuan peternak untuk mengembangkan usahanya semakin 
terbatas. Faktor penghambat lain berupa semakin terbatasnya lahan untuk menerapkan low-cost production system, tantangan iklim/cuaca, serta di beberapa wilayah tertentu adanya keterbatasan infrastruktur dasar, seperti jalan, air bersih, dan listrik.

Proses budidaya sapi perah yang secara alami bersifat labor intensive pada umumnya mampu memberikan income yang memadai bagi peternak, meskipun dengan skala usaha kecil. Di negara berkembang, pada umumnya petani hanya menguasai sepetak kecil lahan yang hanya mampu memberikan income yang relatif kecil pula, maka usaha sapi perah mampu memberikan income yang kontinyu dan mampu memanfaatkan surplus tenaga kerja keluarga. Disisi lain, dengan adanya peningkatan konsumsi produk susu di wilayah perkotaan akan memberikan peluang bagi perkembangan ekonomi di wilayah sentra usaha sapi perah di pedesaan. Peluang seperti ini tidak boleh lepas dari kacamata para decision makers karena jika lepas maka peluang yang ada akan dimanfaatkan oleh negara pengekspor produk susu, seperti Selandia Baru dan Australia. Di sinilah peran Nestle melalui pengembangan milk district model perlu dilakukan upaya revitalisasi agar pemerintah lokal dan para decision makers dapat menangkap peluang yang ada. Nestle secara terus menerus membangun reputasinya melalui pengembangan rantai pasokan (supply chain) dengan mendasarkan pada standar tertinggi keamanan nutrisi pangan yang secara simultan menghormati baik kepentingan produsen dan konsumen. Tujuan kajian ini adalah untuk mendeskripsikan kondisi terkini pengembangan usaha peternakan sapi perah di Jawa Timur berkaitan dengan program milk district model Nestle serta menganalisis strategi perbaikan operasionalisasi milk district model.

\section{Materi dan Metode}

Materi yang digunakan dalam penelitian ini adalah data sekunder tentang perkembangan persusuan dan hasil in-depth interview terhadap keyinformants di Jawa Timur. Materi tersebut digunakan untuk melakukan analisis faktor internal dan eksternal. Metode analisa SWOT digunakan untuk mengevaluasi kondisi perkembangan persusuan di Jawa Timur saat ini dan digunakan untuk membuat rekomendasi strategi untuk mengembangkan milk district model.

\section{Hasil dan Pembahasan}

\section{Konsep milk district model Nestle}

Dalam pengertian sederhana, komponen dari milk district model Nestle meliputi: a) melakukan kesepakatan dengan peternak untuk melakukan pengumpulan susu segar dua kali setiap hari, b) membangun chilling centers dan collection points di desa, c) melakukan pengaturan transpor susu segar dari collection centers ke IPS, dan d) mengimplementasikan program perbaikan kualitas susu segar.

Penentuan lokasi pengembangan usaha sapi perah dilakukan secara mendalam melalui pengamatan berbagai faktor, meliputi: a) Kondisi yang ada pada produksi susu segar dan produksi potensial dari calon lokasi, mendasarkan pada sumber daya pakan, lahan, dan interest peternak terhadap usaha sapi perah. Pertanyaan kuncinya adalah dapatkah potensi lokasi akan mampu memasok bahan baku berupa susu segar bagi IPS secara berkelanjutan?; b) Biaya produksi dan harga susu segar sesuai kondisi yang ada di lokasi; c) Pendapatan peternak sesuai kondisi yang ada di peternak baik dari kegiatan on-farm, off-farm maupun non-farm. Pertanyaan kuncinya adalah apakah susu segar mampu memberikan penghasilan yang memadai bagi peternak?; d) Kondisi sebenarnya dari milk collection systems (jika ada), keberadaaan kompetitor, kondisi kualitas susu segar serta potensi untuk memenuhi persyaratan kualitas yang akan ditetapkan.

Implementasi dari milk district model Nestle meliputi adanya jaminan food safety dan kualitas serta kuantitas, dan adanya jaminan competitiveness. Bahkan sistem food chain dimulai sebelum fase on-farm, berupa riset dan pengembangan sistem budidaya sapi perah. Hal itu dilakukan karena di negara berkembang pada umumnya akan sangat beresiko untuk melakukan pengadaan bahan baku susu segar melalui pihak ketiga tanpa membangun sistem kontrol kualitas di lokasi sentra produksi.

Milk district model Nestle telah terbukti berhasil diimplementasikan di berbagai negara, antara lain di India, Pakistan, China, Brazilia, dan Chilie. Berbagai faktor yang menyebabkan keberhasilan tersebut meliputi adanya extension staff di tingkat desa (agri-service Nestle), adanya peralatan penanganan dan uji kualitas susu segar di tingkat desa, dan adanya operator yang terlatih 
khususnya pada kegiatan pengumpulan susu segar. Disamping itu, juga adanya jaminan penyerapan susu segar yang diproduksi peternak oleh Nestle secara kontinyu sepanjang tahun asal memenuhi kualitas yang dipersyaratkan.

Milk district model Nestle, pada tahapan implementasinya terbukti telah mampu memberikan penghasilan yang reguler bagi para peternak melalui pembayaran susu segar, di Jawa Timur dilakukan setiap sepuluh hari, hal ini akan mampu menggerakkan perekonomian keluarga peternak yang sebelumnya hanya menerima hasil panen budidaya tanaman paling cepat tiga bulan sekali. Dengan kata lain, milk district model Nestle mampu meningkatkan sirkulasi uang di wilayah sentra usaha sapi perah.

Pada tahun 2004, di seluruh dunia Nestle mengeluarkan biaya pengadaan bahan baku susu segar sekitar 2,2 milyar USD, baik pengadaan langsung dari peternak sapi perah maupun dari pihak ketiga. Prinsip Nestle adalah mengembangkan sistem pengadaan langsung dengan peternak sapi perah dan secara eksplisit menggarisbawahi pentingnya aspek sustainabilitas serta perbaikan lingkungan hidup.

Sistem pengadaan bahan baku berupa susu segar berasal dari para peternak sapi perah di Jawa Timur dilakukan oleh Nestle dengan melalui koperasi. Keberadaan koperasi dalam hal ini di satu sisi, dapat dikatakan sebagai pihak ketiga apabila koperasi bukan merupakan representasi para peternak, dan di sisi lain dapat dikatakan koperasi bukan pihak ketiga apabila koperasi benar-benar merupakan representasi para peternak. Pada sistem produksi susu segar dengan rerata kepemilikan ternak sapi perah per peternak berkisar antara 2 sampai 4 ekor induk maka keberadaan koperasi mutlak adanya karena biaya investasi berupa milk cooling unit dan truk susu misalnya tidak mungkin dibayar oleh peternak skala kecil. Investasi tersebut dapat ditangani oleh koperasi sehingga upaya pengembangan usaha sapi perah rakyat mensyaratkan berdirinya koperasi. Permasalahannya adalah seberapa tinggi tingkat representasi koperasi bagi peternak, konkritnya apakah koperasi benar-benar bisa memperjuangkan kepentingan anggotanya.

Pada kondisi sistem produksi susu segar seperti di Jawa Timur maka diperlukan peran Nestle yang lebih besar khususnya dalam memperjuangkan kepentingan peternak sebagai produsen susu segar. Hal itu seiring dengan model bisnis Nestle berupa komitmen jangka panjang dan investasi substansial di negara tempat Nestle beroperasi. Pada edisi pertama dari Nestlé Management and Leadership Principles tahun 1997, dinyatakan bahwa "Investments have to be good for the country as well as good for the company". Hal itu merupakan prinsip dasar karena untuk menciptakan long-term value bagi shareholders, adalah penting untuk menciptakan long-term value bagi masyarakat dimana Nestle beroperasi. Pihak manajemen Nestle mempercayai bahwa filosofi tersebut merupakan salah satu faktor penting bagi penciptaan pertumbuhan bisnis jangka panjang yang menyebabkan Nestle sebagai perusahaan minuman dan makanan terbesar di dunia saat ini. Nestlé corporate business principles, dikaitkan dengan corporate governance principles, dan consumer communication principles adalah merupakan prinsip fundamental yang diimplementasikan di negara tempat Nestle beroperasi dengan memperhatikan aspek politik, sosial, dan kultural yang berlaku, seperti antara lain aspek kesehatan dan nutrisi balita, hak asasi manusia (HAM), tenaga kerja anak, korupsi, dan lingkungan hidup.

Prinsip-prinsip tersebut dikembangkan dengan pedoman: a) Tujuan bisnis Nestle adalah untuk memproduksi dan memasarkan produk dengan cara yang dapat menciptakan nilai (value) yang berkelanjutan bagi shareholders, karyawan, konsumen, partner bisnis dan perekonomian nasional/regional tempat Nestle beroperasi, b) Nestle tidak menghendaki short-term profit yang baik secara langsung maupun tidak langsung dibiayai oleh keberhasilan pengembangan bisnis jangka panjang, c) Nestle memahami bahwa konsumen/pelanggan memiliki perhatian dan legitimasi perilaku, kepercayaan dan tindakan perusahaan di balik brands di mana mereka telah menaruh kepercayaan, dan d) Nestle beroperasi di berbagai negara dengan berbagai budaya di seluruh dunia, kondisi keanekaragaman yang kaya ini merupakan suatu sumber yang tidak ternilai bagi kepemimpinan Nestle.

Untuk keperluan analisis Corporate Social Responsibility (CSR), maka sistem produksi susu segar di Jawa Timur dilihat sebagai satu kesatuan asosiatif dari beragam kegiatan yang sebenarnya terpisah. Basic road map sistem persusuan Jawa Timur, berawal dari produksi (industri biologis) pada tingkatan rumah tangga petani-ternak sapi perah sampai dengan pedagang (wholesaler).

Sejalan dengan prinsip dan etika bisnis yang ditetapkan, maka operasi model Nestlé milk district di Jawa Timur tentu diharapkan dapat memberikan dampak pada rumah tangga petani-ternak sapi perah yang lebih berdaya, di samping sebagai bentuk tanggung jawab sosial kepada masyarakat luas. Paling tidak, dengan usia operasi selama lebih dari 20 tahun di Jawa Timur, ada jejak Nestlé yang perlu dikaji secara eksplisit selain business-benefits, meliputi community-benefits pada resource-pool dan consumers. Untuk rumah tangga petani-ternak sapi perah di pedesaan sebagai suatu resource-pool, 
maka kajiannya meliputi job-creation, capacitybuilding for local community, know-how and technology transfer, serta improved business environment and investment climate. Dilihat dari sisi consumers, maka ada kepentingan untuk mengkaji creation of access to quality products and services, lower prices, improved quality of life and improved productivity.

Kofi Annan, Sekretaris Jenderal PBB, menyatakan bahwa ada banyak cara positif bagi industri untuk membuat perbedaan dalam kehidupan masyarakat miskin tanpa melalui sumbangan, meskipun hal ini juga penting, tetapi melalui inisiatif yang pada waktunya akan membantu mereka membangun pasar baru (Poulton, 2000). Membuat rumah tangga masyarakat petaniternak sapi perah di pedesaan menjadi berdaya atau lebih berdaya melalui perbaikan kondisi livelihoods-nya dan berbagai inisiatif, bagi Kofi Annan tampak merupakan kewajiban moral bagi institusi bisnis. Oleh karena itu, pertanyaan dasar yang perlu dijawab pada analisis CSR adalah seperti apakah keragaman bukti kehadiran model Nestlé milk district di Jawa Timur pada masyarakat petaniternak sapi perah khususnya, masyarakat pedesaan dan masyarakat konsumen pada umumnya.

The Department for International Development (DFID, 1999) memberikan kerangka konseptual (framework) yang menjadi landasan penting bagi perumusan program-program aksi dalam implementasi proyek pemberantasan kemiskinan dan keterbelakangan (poverty alleviation and deprivations) yang secara kronik diakui terjadi di banyak negara-negara berkembang. Di samping itu, framework tersebut telah pula menjadi pijakan bagi kegiatan evaluasi terhadap kondisi tertentu pada masyarakat yang dikenai 'intervensi', vulnerablevulnerability (rentan-kerentanan) (Manuvanduse et al., 2000) pada suatu komunitas yang kemungkinan terkena dampak (shocks, trends, seasonality) implementasi suatu kebijakan pemerintah atau bahkan kerusakan lingkungan yang dapat menyeret perikehidupan suatu komunitas kepada situasi kebangkrutan total. Dengan demikian, di dalam konteks operasi model Nestlé milk district di Jawa Timur, disamping memunculkan diskusi tentang kisah suksesnya, tidak kalah penting juga usaha untuk memasalahkan hal-hal faktual yang menyangkut implikasi implementasi model operasi tersebut, utamanya seberapa jauh program telah mempengaruhi hidup, kehidupan, dan penghidupan masyarakat dalam lingkup yang sama ataupun berbeda.

Secara empiris, hampiran analisis mendasarkan sepenuhnya kepada fakta dan informasi dampak yang terekam pada instrumen yang dikembangkan untuk keperluan kajian ini, untuk kemudian dikaitkan dengan 5 hal sebagaimana diekspresikan oleh bangun segi lima (pentagonal-shape) yang terdiri dari 5 macam elemen capital (Gambar 1)

Tabel 1. Kerangka kerja untuk menciptakan Shared-Value (frame work for creating Shared-Value)

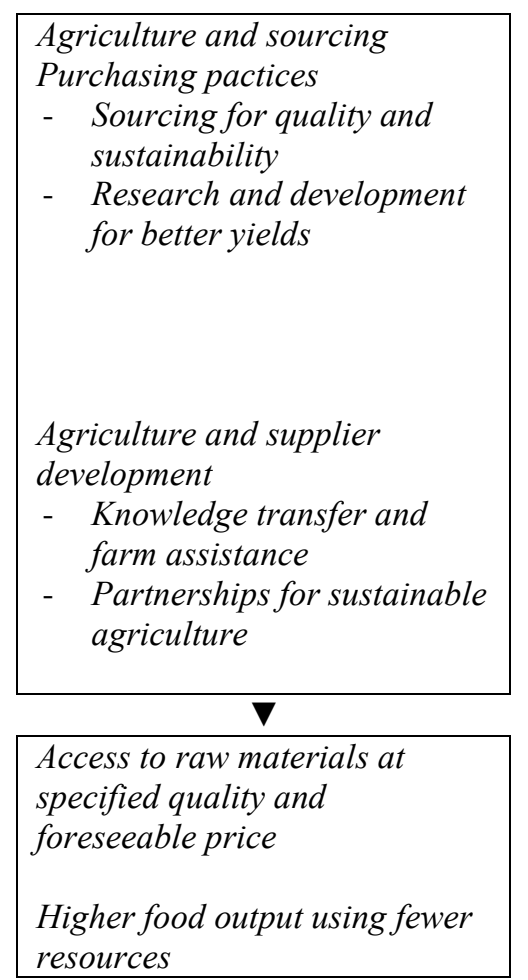

Sumber: Ashley dan Hussein (2000).

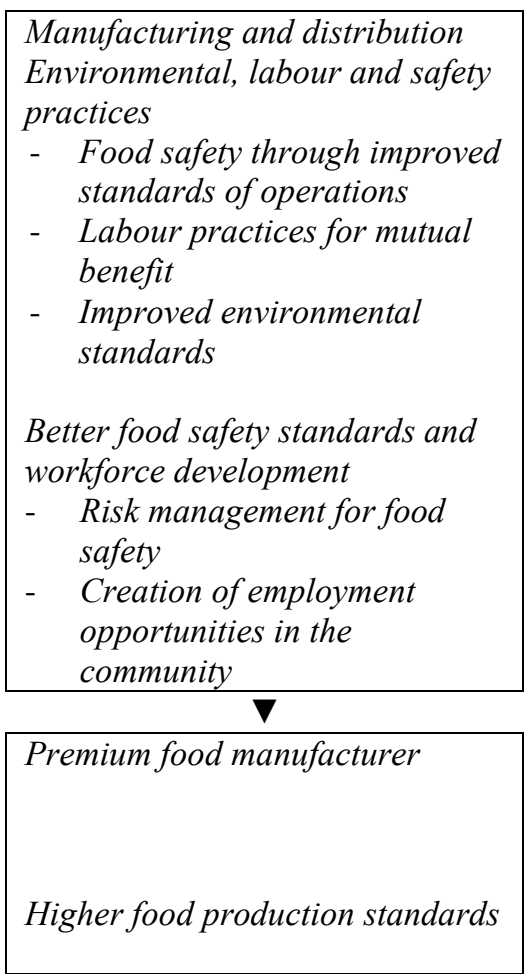

Products and cunsumers New innovated products for nutrition, health and wellness

- Research for consumer benefit

- Consumer nutrition, health and wellness

Increase knowledge and awareness for healthy nutrition and lifestyles

- Knowledge and education for healthy nutrition and lifestyles

Profitable growth from superior
product benefits
Wider access to food, and
improved nutrition and health


yang secara empiris sangat dekat atau bahkan mungkin simetris dengan kemampuan sekelompok orang atau seseorang (petani-ternak) dalam hal menyangkut assets (wealth-stocks) atau akses yang meliputi akses sumber daya manusia (human capital), akses sumber daya alam (natural capital), akses finansial (financial capital), akses sumber daya fisik (physical capital), dan akses sumber daya sosial (social capital).

Pada prinsipnya, pendekatan sustainable livelihoods disarankan seyogyanya diadopsi sebagai orientasi pikir para aktor pembangunan 'to promote development that is sustainable not just ecologically, but also institutionally, socially, and economically and to produce genuinely positive livelihood outcomes' (Ashley dan Hussein, 2000). Kondisi seperti tersebut hanya mungkin dapat dicapai melalui beragam pendekatan yang saling melengkapi satu dengan lainnya yaitu pendekatan people-centred, responsive and participatory, multilevel, conducted in partnership, sustainable with the four key dimensions of sustainability being economic, institutional, social and environmental, and dynamic. Pengertian the pentagon of assets yang ada pada masyarakat (Gambar 1) termasuk hal yang substansial pula untuk diperhatikan dalam kajian ini (Ashley dan Hussein, 2000). Penjelasannya adalah bahwa menurut teori sustainable livelihoods (DFID, 1999), suatu livelihoods yang merupakan kombinasi beragam sumber daya yang diperebutkan untuk digunakan oleh masyarakat dalam aneka aktivitas mereka dalam rangka untuk mengisi hidup, bertahan hidup, dan berkembang. Sumber daya yang dimaksud adalah segala sesuatu yang berkait dengan kebutuhan masyarakat dalam daya upaya mereka untuk melangsungkan dan mengamankan kehidupannya. Sebagai contoh, yang termasuk di dalam sumber daya antara lain adalah keterampilan dan kebisaan seseorang adalah termasuk sumber daya manusia, lahan dan beragam bentuk simpanan atau peralatan yang dimiliki termasuk di dalam kategori sumber daya alam, sumber daya finansial atau sumber daya fisik, kelompok atau jalinan interaksi dengan kelompok atau individu lain sebagai sumber daya sosial.

Livelihoods dapat dinyatakan sustainable jika dia dapat disatupadukan dan dipakai oleh individu atau kelompok untuk meredam dan memulihkan kondisi dari adanya berbagai guncangan dan tekanan, mempertahankan atau bahkan mengembangkan aset modal yang mereka miliki atau kuasai, dan yang terakhir adalah bahwa, dalam aktivitas pendayagunaannya, livelihoods tidak sampai menimbulkan resiko ancaman terhadap kelestarian sumber daya alam di sekitarnya (Johnson, 2000).

Sementara itu, dalam upaya mempertajam kerangka pikir sustainable livelihoods, Singh dan Gilman (2001) mengidentifikasi beberapa macam aset penting yang ada di dalam suatu komunitas dan vital pengaruhnya pada sustainable livelihoods framework (Gambar 2), mereka menyebut aset suatu komunitas dengan istilah wealth stock yang selanjutnya diurai ke dalam 5 macam capital, sama persis seperti yang disampaikan DFID (1999).

Dengan demikian dapat dengan mudah dimengerti bahwa elemen-elemen livelihoods (memakai istilah DFID, 1999) atau wealth stock (meminjam istilah Singh dan Gilman, 2001) suatu rumah tangga di pedesaan ataupun sekelompok orang di dalam suatu komunitas dapat berubah setiap saat (Cleary et al., 2003), sebagai akibat

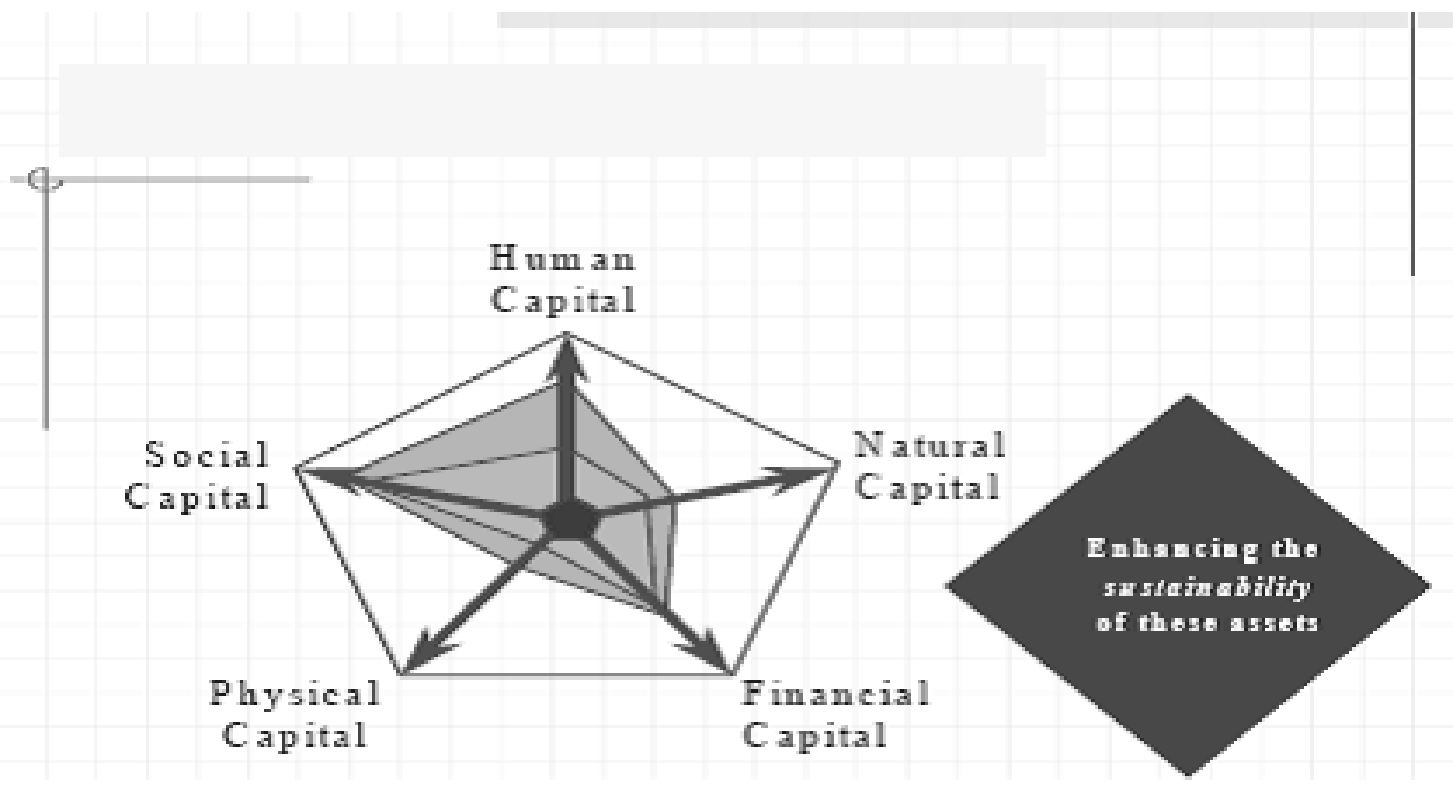

Gambar 1. Pentagonal aset (the pentagon of assets) (Singh dan Gilman, 2001). 


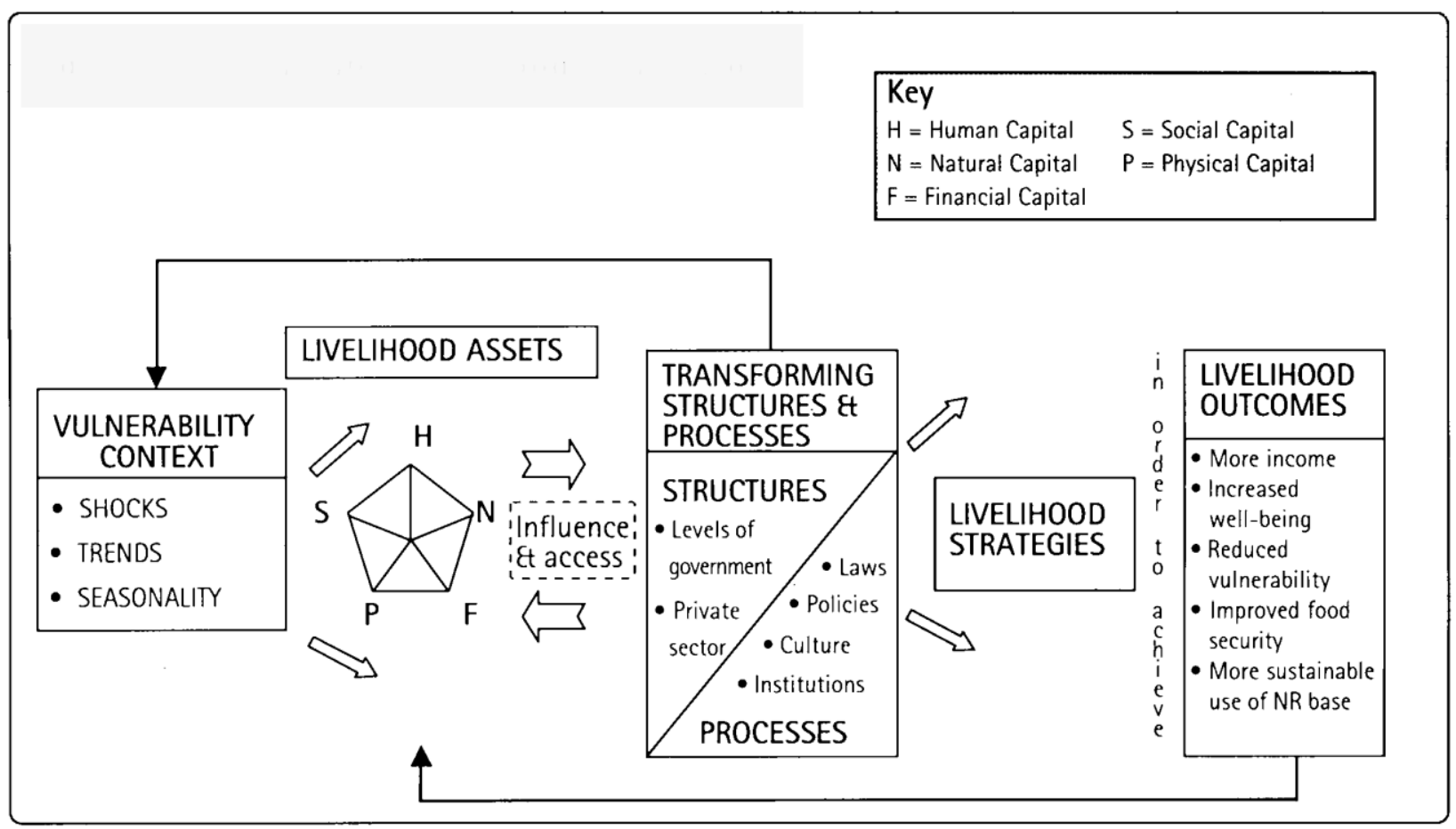

Gambar 2. Kerangka kerja livelihoods yang sustainable (sustainable livelihoods framework) (DFID, 1999).

merespon segala sesuatu stimulan yang berasal dari dalam ataupun dari luar, maupun bahkan dari kedua-duanya pada waktu bersamaan.

Stimulan dari dalam, sebagai contoh misalnya, suatu rumah tangga pedesaan memiliki seorang anak yang akan melanjutkan sekolah, dari lulus sekolah dasar ke sekolah lanjutan pertama yang tentunya memerlukan biaya makin besar. Untuk memenuhi hal itu, rumah tangga bersangkutan tentu harus merubah titik kedudukan elemen financial capital pada sumbu the pentagon of assets pada posisi makin mendekat ke arah titik pusat, yang artinya bahwa rumahtangga tersebut harus mengurangi besaran kepemilikan finansial (wealth stock financial, harus mengeluarkan sejumlah uang untuk membayar) untuk memenuhi kebutuhan menyekolahkan anaknya. Pada saat bersamaan, dengan masuknya anak ke sekolah menengah lanjutan pertama, maka kedudukan titik pada sumbu human capital bergerak makin menjauh dari pusat the pentagon of assets yang berarti pula human capital pada rumah tangga bersangkutan bertambah. Kemungkinan berikutnya adalah jika rumah tangga memutuskan menjual sebanyak 3 kuintal gabah bagian persediaan pangan mereka yang mereka simpan dari hasil panen budidaya tanaman sebelumnya, atau rumah tangga memutuskan menjual seekor dari 2 ekor sapi perah dara yang berhasil mereka miliki, maka berarti rumah tangga memperkecil physical capital dari livelihoods mereka. Rumah tangga bersangkutan akan memiliki sisa uang dari penjualan intangible assets (berupa padi atau sapi) jika ternyata harga yang berlaku di pasar (external trends dan seasonality) ternyata lebih tinggi dari yang diperhitungkan sebelumnya, pada kondisi seperti itu, posisi titik financial capital makin menjauh dari pusat the pentagon of assets. Demikianlah, posisi titik livelihoods atau wealth stock pada masing-masing sumbu the pentagon of assets setiap saat dapat berubah, karena komunitas secara alamiah bereaksi terhadap shocks, trends, dan seasonality.

Disadari, pendekatan livelihoods yang dipakai oleh kajian ini sejak semula memang tidak dirancang untuk melihat perubahan suatu fenomena perubahan-perubahan menyangkut struktur sistem maupun fungsi sistem di dalam livelihoods secara historikal ketat. Secara metodologis, paramater dan indikator keragaan elemen wealth-stocks diuraikan di dalam instrumen (kuesioner) (Gambar 3).

\section{Analisis situasi: agribisnis susu segar di Jawa Timur}

Agribisnis sapi perah di Indonesia telah berkembang sebagai usaha keluarga sejak masa penjajahan, dengan mendatangkan sapi perah $\mathrm{FH}$ dari Belanda. Sejak tahun 1970, agribisnis sapi perah berkembang menjadi usaha swasta skala menengah, tetapi hanya terdapat secara terbatas pada wilayahwilayah tertentu. Pada tahun 1978, pemerintah menggerakkan perkembangan agribisnis sapi perah, yang diawali dengan instrumen kebijakan penanaman modal asing (PMA) dalam IPS. Sedangkan budidaya sapi perah tertutup bagi modal asing. Pada tahun 1980, pemerintah menerbitkan SKB tiga menteri yang mengatur bahwa agribisnis sapi perah 
merupakan usaha rakyat dan dikembangkan melalui koperasi dan koperasi mewakili peternak dalam kerjasama pemasaran susu dengan IPS. Sampai dengan tahun 1997, pemerintah telah menerbitkan berbagai peraturan yang meliputi hampir seluruh simpul kegiatan ekonomi industri untuk mengamankan SKB tiga menteri, sehingga dapat dikatakan bahwa intervensi pemerintah dalam ekonomi industri sapi perah sangat kental.

Tahun 1998 setelah krisis ekonomi, pemerintah melakukan deregulasi dan membiarkan aktivitas ekonomi industri berjalan di pasar secara bebas. Tetapi, industri agribisnis sapi perah nasional belum dapat lepas landas, karena struktur industri dan pasar yang ada merupakan produk masa lalu yang harus ditata kembali ke arah bentuk struktur yang efektif untuk segera berkembang. Banyak masalah yang dihadapi antara lain bagaimana menyelamatkan nasib ribuan para peternak rakyat dan bagaimana harus mengembangkan sistem agribisnis yang terintegrasi antara pelaku-pelaku ekonomi persusuan.

IPS skala besar di Indonesia berjumlah sekitar 7 buah dan sebagian besar bersifat PMA. Pembangunan IPS ini hampir seluruhnya di wilayah pusat konsumsi yakni daerah urban Jakarta, sementara produsen susu segar sebagian besar berada di wilayah pedesaan khususnya Malang, Pasuruan, Yogyakarta, Boyolali, dan Bandung. Tahap awal pembangunan industri sapi perah memang dimotori oleh pembangunan IPS, sekalipun agribisnis sapi perah dalam negeri belum berkembang untuk mendukung kehadiran IPS tersebut. Oleh karenanya dapat dipahami bahwa pembangunan IPS pada lokasi wilayah pusat konsumsi adalah atas pertimbangan kemudahan dalam mengimpor bahan baku susu dari pasar dunia. Kondisi ini membuktikan bahwa pemerintah dan pengusaha IPS, sejak semula tidak sepenuhnya bermaksud mengkaitkan pembangunan IPS dengan produksi susu dalam negeri.

Simpul pelaku ekonomi kedua yang berperan besar dalam pengembangan agribisnis sapi perah setelah IPS adalah koperasi sapi perah dan KUD yang bernaung di bawah Gabungan Koperasi Susu Indonesia (GKSI). GKSI merupakan satu-satunya organisasi sapi perah yang berkantor pusat di Jakarta. GKSI mempunyai perwakilan pada setiap provinsi yang disebut koordinator daerah (Korda) GKSI. Korda GKSI mengorganisir koperasi-koperasi sapi perah yang terdapat pada setiap kecamatan. Koperasi yang berada pada tingkat kecamatan (satu kecamatan hanya ada satu koperasi) berfungsi mengorganisir para peternak sapi perah rakyat yang menjadi anggota (GKSI, 2000). Sejarah memperlihatkan bahwa pemerintah mempunyai peran yang besar dalam pembentukan GKSI, pembentukan koperasikoperasi di kecamatan dan juga berperan sangat besar dalam menghimpun masyarakat menjadi peternak dan anggota koperasi melalui fasilitas kredit berbunga rendah.

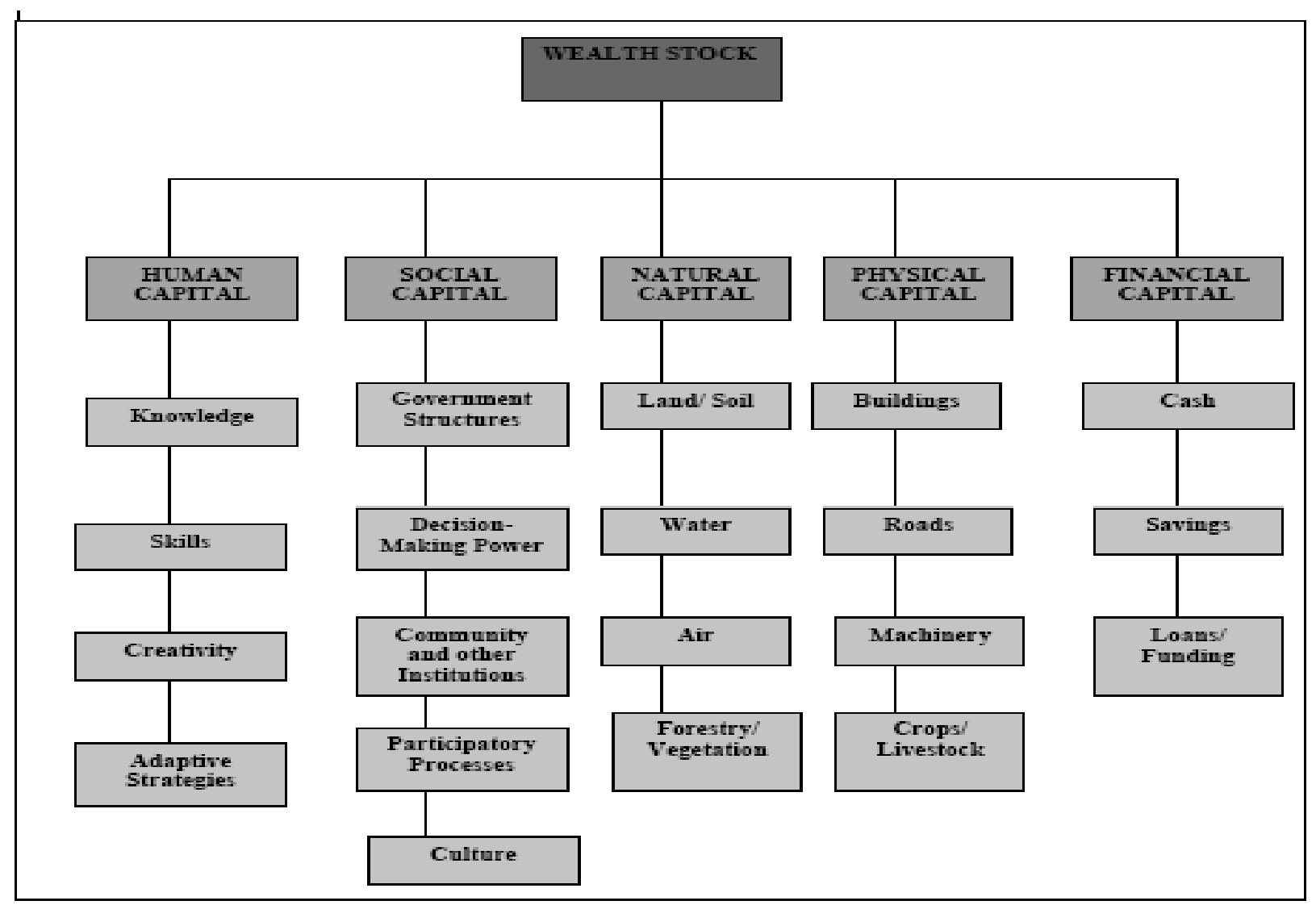

Gambar 3. Wealth-stocks (Singh dan Gilman, 2001). 
Budidaya sapi perah sebagian besar didominasi oleh peternakan rakyat dengan skala pemilikan kecil antara 1 sampai 3 ekor sapi betina produktif. Mereka sebagian besar bergabung dalam koperasi atau KUD. Jumlah peternak rakyat terus meningkat dari tahun ke tahun tetapi citra usaha rakyat tidak pernah berkembang, baik teknologi budidaya maupun skala usaha. Smith dan Riethmuller (1995) berhasil merumuskan beberapa masalah industri sapi perah di Indonesia, diantaranya adalah hijauan ternak yang kurang, pakan konsentrat yang bermutu rendah, cara pemberian makanan yang buruk, kesehatan ternak yang rendah, tidak ada pencatatan produksi, mutu bibit yang rendah, serta penyuluhan yang tidak intensif.

Pertanyaan penting adalah mengapa teknologi, budidaya dan citra usaha ternak tidak mengalami perubahan ke arah citra yang lebih baik. Citra usaha rakyat tetap usaha ekonomi dengan skala kecil yang tidak efisien. Untuk mendalami hal ini, maka langkah awal adalah mempertanyakan apakah peternak mendapat bagian yang layak secara finansial dalam melaksanakan fungsinya sebagai pengusaha.

Produksi susu segar di Indonesia saat ini hanya mampu mencukupi kebutuhan domestik sekitar 35\% dan sisanya 65\% harus diimpor dari luar negeri. Australia merupakan pemasok utama produk susu ke Indonesia, dengan nilai sekitar 126 juta USD pada tahun 2005, diikuti oleh Selandia Baru 107 juta USD, kemudian masyarakat eropa 102 juta USD. Produk utama yang diimpor dari Australia ke Indonesia berupa skim dan whole milk powder, diikuti dengan cheese, whey, dan butter.

Perusahaan, koperasi dan industri rumah tangga yang bergerak di bidang pengolahan susu segar di Jawa Timur berjumlah 15 unit, terdiri dari: 1) PT Nestle Indonesia, Tbk, Pasuruan, 2) PT Indo Murni Dairy Industri, Pasuruan, 3) PT Greenfields Indonesia, Malang, 4) PKIS Sekar Tanjung, Pasuruan, 5) Koperasi Setia Kawan, Pasuruan, 6)
Koperasi Dau, Malang, 7) SAE Pujon, Malang; 8) Unit Pengolahan Keju, Malang, 9) Balai Diklat Agribisnis dan Teknologi Hasil Ternak, Batu, 10) Koperasi Batu, 11) Perusahaan Susu Mulia, Sidoarjo, 12) BPT dan HMT Karangwaru, Tuban, 13) BPT dan HMT Batu, Batu, 14) BPT dan HMT Singosari, Malang, dan 15) BPT dan HMT Branggahan, Kediri. Jenis produk yang dihasilkan terdiri dari: susu segar, susu pasteurisasi, UHT, susu bubuk, susu kental manis, es krim, keju, dodol susu dan karamel susu.

Produksi susu segar di Jawa Timur tercatat sekitar 739 ton per hari pada tahun 2005, dari sejumlah itu sebagian besar diserap oleh PT Nestle Indonesia $(65,76 \%)$, sedangkan urutan kedua ditempati oleh GKSI Jawa Tengah yang menyerap sekitar $13,53 \%$.

\section{Analisis lingkungan internal dan eksternal}

Mendasarkan pada hasil yang tertera pada matrik IFAS (Tabel 3) dan EFAS (Tabel 4), maka dapat disimpulkan bahwa operasionalisasi dari milk district model Nestlé disatu sisi secara internal negatif karena nilai skor $\mathrm{S}(1,98)$ lebih kecil dari pada nilai skor W $(3,72)$, sedangkan disisi lain secara eksternal positif karena nilai skor $O(2,19)$ lebih besar dari nilai skor $\mathrm{T}(1,35)$. Oleh karenanya jenis strategi terpilih yang perlu dilakukan untuk perbaikan operasionalisasi dari milk district model Nestlé adalah stability strategy. Dalam artian karena nilai skor O $(2,19)$ lebih kecil dari pada nilai skor W $(3,19)$ maka maka perlu dilakukan pembenahan secara selektif, yang lebih difokuskan pada upaya self evaluation terhadap peran dari masing-masing stakeholders yang terkait dengan kegiatan usaha agribisnis sapi perah di Jawa Timur. Stakeholders tersebut meliputi peternak, koperasi, IPS, suppliers sapronak, pemerintah, instansi/dinas terkait, serta perguruan tinggi dan lembaga swadaya masyarakat (LSM).

Tabel 2. Pemasaran susu segar di Jawa Timur tahun 2005 (freshmilk marketing in East Java in 2005)

\begin{tabular}{clcr}
\hline \hline No. & Industri pengolah (pricesing company) & Jumlah (ton/hari) & (volume (ton/day)) \\
\hline 1 & PT Nestle Indonesia & 486,00 & 65,76 \\
2 & PT Greenfields & 10,00 & 1,35 \\
3 & PT IMDI & 45,00 & 6,09 \\
4 & PKIS Sekar Tanjung & 40,00 & 5,41 \\
5 & KUD Dau & 2,00 & 0,27 \\
6 & GKSI Jateng & 100,00 & 13,53 \\
7 & KUD Batu & 7,00 & 0,95 \\
8 & PT Sari Husada & 10,00 & 1,35 \\
9 & PT FVI & 30,00 & 4,06 \\
10 & Konsumen langsung & 9,00 & 1,22 \\
\hline \multicolumn{2}{r}{ Jumlah } \\
\hline
\end{tabular}

Sumber: Dinas Peternakan Jawa Timur (Dispetprov Jatim, 2006). 
Tabel 3. Internal factor analysis summary (IFAS)

\begin{tabular}{|c|c|c|c|c|}
\hline No. & Faktor (factor) & $\begin{array}{l}\text { Bobot } \\
(\text { value })(a)\end{array}$ & $\begin{array}{c}\text { Skor } \\
(\text { score })(b)\end{array}$ & $\begin{array}{l}\text { Skor total } \\
\text { (total score) } \\
\text { (a) x (b) }\end{array}$ \\
\hline \multicolumn{5}{|c|}{ Strengths $(\mathbf{S})$} \\
\hline 1 & $\begin{array}{l}\text { Sapi perah FH lokal telah beradaptasi dengan lingkungan } \\
\text { setempat }\end{array}$ & 0,03 & 3,00 & 0,09 \\
\hline 2 & Telah memanfaatkan teknologi reproduksi IB & 0,05 & 3,00 & 0,15 \\
\hline 3 & Tingginya trend permintaan susu segar & 0,08 & 4,00 & 0,32 \\
\hline 4 & Adanya dukungan kebijakan pemerintah & 0,08 & 4,00 & 0,32 \\
\hline 5 & Mampu membuka peluang kerja di pedesaan & 0,05 & 3,00 & 0,15 \\
\hline 6 & Tersedianya SDA yang relatif mencukupi & 0,03 & 3,00 & 0,09 \\
\hline 7 & Tingginya interest peternak pada kegiatan budidaya sapi perah & 0,05 & 3,00 & 0,15 \\
\hline 8 & Kondisi klimat relatif mendukung & 0,05 & 3,00 & 0,15 \\
\hline 9 & Berbasis pada usaha keluarga & 0,03 & 3,00 & 0,09 \\
\hline 10 & Adanya layanan koperasi untuk pengadaan sapronak & 0,05 & 3,00 & 0,15 \\
\hline \multirow[t]{2}{*}{11} & Adanya jaminan pasar dari pihak IPS & 0,08 & 4,00 & 0,32 \\
\hline & Sub total & $\mathbf{0 , 5 8}$ & & 1,98 \\
\hline \multicolumn{5}{|c|}{ Weaknesses $(\mathrm{W})$} \\
\hline 1 & Rerata produksi susu rendah ( $<10$ liter per ekor) & 0,05 & 3,00 & 0,15 \\
\hline 2 & $\begin{array}{l}\text { Kebijakan pemuliaan khususnya rekording belum terprogram } \\
\text { dengan baik }\end{array}$ & 0,05 & 3,00 & 0,15 \\
\hline 3 & Tingginya angka service per conception & 0,08 & 4,00 & 0,32 \\
\hline 4 & Kurang tersedianya fasilitas air bersih & 0,03 & 3,00 & 0,09 \\
\hline 5 & $\begin{array}{l}\text { Kurang tersedianya hijauan pakan, khususnya pada musim } \\
\text { kemarau }\end{array}$ & 0,05 & 3,00 & 0,15 \\
\hline 6 & Kurang memadainya kualitas pakan penguat & 0,05 & 3,00 & 0,15 \\
\hline 7 & Relatif tingginya angka TPC & 0,08 & 4,00 & 0,32 \\
\hline \multirow[t]{2}{*}{8} & Belum sepenuhnya memanfaatkan limbah kandang & 0,03 & 3,00 & 0,09 \\
\hline & Sub total & $\mathbf{0 , 4 2}$ & & 3,72 \\
\hline Tota & & 1,00 & & \\
\hline
\end{tabular}

Fokus strategi bagi para peternak lebih diarahkan pada berbagai upaya untuk mengintroduksikan program-program reguler berjangka panjang dengan target perubahan mindset agar mereka secara bertahap mengurangi ketergantungan terhadap bahan baku pakan asal impor melalui pemanfaatan sumber daya alam lokal, dan mengolah/memanfaatkan limbah kandang, serta perubahan mindset mereka agar secara bertahap sadar dan berpartisipasi aktif dalam product line kegiatan proses produksi industri pengolahan susu segar sehingga mereka akan memilki self responsibility terhadap standar kualitas susu segar yang mereka hasilkan.

Fokus strategi bagi koperasi lebih diarahkan pada berbagai upaya perbaikan kualitas sumber daya manusia para pengelola sehingga mereka akan mampu berpikir secara strategis dan lebih mengutamakan benefit ketimbang profit, melalui berbagai leadership training, benchmarking serta penerapan berbagai sistem insentif berbasis kinerja. Sedangkan bagi kelembagaan koperasi, fokus strateginya lebih diarahkan pada penciptaan situasi yang kondusif melalui instrumen kebijakan pemerintah, misalnya dengan program insentif sehingga secara bertahap akan terjadi perubahan peran koperasi yang sebelumnya sebagai profit centers ke arah service centers.

Fokus strategi bagi IPS lebih diarahkan pada berbagai upaya revitalisasi peran IPS dalam tahapan hulu (pengadaan sapronak dan budidaya) melalui berbagai jenis kegiatan technical assistances, fasilitas kredit lunak, serta sebagai avalist (penjamin) kredit sapi induk. Selama ini peran IPS sudah sangat besar khususnya pada tahapan hilir (distribusi susu segar) melalui bantuan teknis dan peralatan, namun perannya pada tahapan hilir masih dirasa kurang. Memang benar adanya bahwa kompetensi IPS bukan pada tahapan hulu akan tetapi apabila diamati dari product line, jelas kualitas produk pada tahapan hilir sangat bergantung pada jenis dan kualitas kegiatan pada tahapan hulu. Untuk itu, sudah saatnya IPS berperan pada tahapan hulu, apalagi jika IPS menargetkan untuk meningkatkan kapasitas produksinya dalam jangka panjang maka hal itu sangat krusial untuk dilakukan. Salah satu alternatifnya antara lain agar IPS menstimulir terbentuknya kegiatan pengembangan usaha ternak sapi perah dengan pola cluster development partnership. 
Tabel 4. External factor analysis summary (EFAS)

\begin{tabular}{|c|c|c|c|c|}
\hline No. & Faktor (factor) & $\begin{array}{c}\text { Bobot } \\
(\text { value })(a)\end{array}$ & $\begin{array}{l}\text { Skor } \\
(\text { score })(b)\end{array}$ & $\begin{array}{l}\text { Skor total } \\
\text { (total score) } \\
\text { (a) } \mathrm{x} \text { (b) }\end{array}$ \\
\hline \multicolumn{5}{|c|}{ Opportunities (O) } \\
\hline 1 & $\begin{array}{l}\text { Pemanfaatan pedet sapi perah jantan untuk usaha fattening } \\
\text { secara komersial }\end{array}$ & 0,05 & 3,00 & 0,15 \\
\hline 2 & Pemanfaatan limbah kandang untuk biogas dan pupuk cair & 0,10 & 3,00 & 0,30 \\
\hline 3 & $\begin{array}{l}\text { Pengembangan usaha sapi perah dengan pola cluster } \\
\text { development partnership }\end{array}$ & 0,10 & 4,00 & 0,40 \\
\hline 4 & Pengembangan program rekording melalui sistem insentif & 0,08 & 3,00 & 0,24 \\
\hline 5 & $\begin{array}{l}\text { Pengembangan program konsumsi susu segar bagi anggota } \\
\text { keluarga peternak melalui sistem insentif }\end{array}$ & 0,10 & 3,00 & 0,30 \\
\hline 6 & $\begin{array}{l}\text { Diperlukan instrumen kebijakan pemerintah agar tercipta kondisi } \\
\text { friendly market mechanism khususnya pada aspek distribusi susu } \\
\text { segar dan pengadaan bahan pakan penguat }\end{array}$ & 0,10 & 4,00 & 0,40 \\
\hline 7 & $\begin{array}{l}\text { Pergeseran peran koperasi dari profit center ke arah service } \\
\text { center }\end{array}$ & 0,10 & 4,00 & 0,40 \\
\hline & Sub total & $\mathbf{0 , 6 3}$ & & 2,19 \\
\hline \multicolumn{5}{|c|}{ Threats $(\mathbf{T})$} \\
\hline 1 & $\begin{array}{l}\text { Penggunaan pejantan IB/kawin alam belum terkontrol secara } \\
\text { baik akan menyebabkan peningkatan koefisien inbreeding }\end{array}$ & 0,08 & 4,00 & 0,32 \\
\hline 2 & $\begin{array}{l}\text { Tingkat ketergantungan yang tinggi terhadap bahan pakan asal } \\
\text { impor, khususnya pollard }\end{array}$ & 0,08 & 4,00 & 0,32 \\
\hline 3 & $\begin{array}{l}\text { Belum tersedianya upaya yang terprogram bagi kegiatan calf } \\
\text { rearing untuk replacement sapi induk }\end{array}$ & 0,08 & 3,00 & 0,24 \\
\hline 4 & $\begin{array}{l}\text { Semakin bertambahnya jumlah IPS yang menampung susu segar } \\
\text { sehingga akan menimbulkan persaingan yang kurang sehat }\end{array}$ & 0,08 & 4,00 & 0,32 \\
\hline \multirow[t]{2}{*}{5} & Adanya fluktuasi nilai tukar dollar terhadap rupiah & 0,05 & 3,00 & 0,15 \\
\hline & Sub total & $\mathbf{0 , 3 7}$ & & 1,35 \\
\hline Tota & & 1,00 & & \\
\hline
\end{tabular}

Fokus strategi bagi pemerintah, instansi/dinas terkait, serta perguruan tinggi dan LSM lebih diarahkan pada berbagai upaya revitalisasi peran mereka sebagai agent of changes. Pemerintah berperan dalam penciptaan berbagai kebijakan dan peraturan berupa berbagai jenis instrumen kebijakan dan program insentif berbasis kinerja, sedangkan instansi/dinas terkait dan perguruan tinggi serta LSM dapat berperan aktif dalam berbagai kegiatan technical assistances.

Guna perbaikan operasionalisasi milk district model Nestle di Jawa Timur maka kedepan diperlukan empat jenis strategi, meliputi revitalisasi peran peternak, revitalisasi peran koperasi, revitalisasi peran IPS, dan revitalisasi peran pemerintah, instansi/dinas terkait, serta perguruan tinggi dan LSM. Secara rinci jenis strategi, program dan kegiatan disajikan pada Tabel 5 .

\section{Kesimpulan}

Untuk operasionalisasi milk district model perlu 1) dilakukan upaya untuk meningkatkan partisipasi aktif para peternak dalam product line industri pengolahan susu segar pada tahapan hulu (budidaya) melalui perubahan mindset pembentukan self responsibility para peternak terhadap pencapaian standar kualitas susu segar, 2) dilakukan upaya untuk memanfaatkan semaksimal mungkin bahan baku lokal pakan penguat melalui perubahan mindset para peternak agar tingkat ketergantungan terhadap bahan baku pakan asal impor dapat diminimumkan, 3) dilakukan upaya untuk memanfaat-kan limbah kandang (feses dan urin) melalui produksi biogas dan pupuk cair agar potensi timbulnya pencemaran air baku di daerah hilir dapat diminimumkan, serta dapat mengurangi pengeluaran biaya bahan bakar rumah tangga peternak, 4) di-lakukan upaya perbaikan kualitas sumber daya manusia pengelola koperasi agar lebih berkarakter strategis sehingga lebih fokus kepada benefit daripada profit, 5) dilakukan berbagai upaya agar di masa mendatang terjadi perubahan peran koperasi dari profit centers menjadi service centers melalui penerapan sistem insentif berbasis kinerja, 6) dilakukan perluasan peran IPS khususnya pada tahapan hulu agar pencapaian standar kualitas susu segar dapat diraih secara berkelanjutan, 
Tabel 5. Matrik strategi dan program perbaikan operasionalisasi milk district model Nestlé (strategy and milk district model improvement matrix)

\begin{tabular}{|c|c|c|}
\hline No & Strategi (strategy) & Program (program) \\
\hline \multirow[t]{3}{*}{1} & $\begin{array}{l}\text { Revitalisasi peran pe- } \\
\text { ternak dalam operasio- } \\
\text { nalisasi milk district } \\
\text { model Nestlé }\end{array}$ & $\begin{array}{l}\text { a. Perubahan mindset melalui } \\
\text { pembentukan self respon- } \\
\text { sibility terhadap pencapaian } \\
\text { target kualitas susu segar }\end{array}$ \\
\hline & & $\begin{array}{l}\text { b. Perubahan mindset untuk } \\
\text { mengurangi ketergantungan } \\
\text { terhadap bahan baku pakan asal } \\
\text { impor }\end{array}$ \\
\hline & & $\begin{array}{l}\text { Perubahan mindset untuk } \\
\text { memanfaatkan limbah kandang } \\
\text { (feses dan urin) melalui } \\
\text { produksi biogas dan pupuk cair }\end{array}$ \\
\hline
\end{tabular}

\begin{tabular}{llll}
\hline 2 & $\begin{array}{l}\text { Revitalisasi peran ko- } \\
\text { perasi dalam operasio- } \\
\text { nalisasi milk district } \\
\text { model Nestlé }\end{array}$ & & $\begin{array}{l}\text { Perbaikan kualitas SDM } \\
\text { pengelola koperasi }\end{array}$ \\
& b. $\begin{array}{l}\text { Perubahan peran koperasi dari } \\
\text { profit centers menjadi service } \\
\text { centers }\end{array}$
\end{tabular}

Kegiatan (activity)

a. Menyelenggarakan kegiatan tour of factory secara reguler

b. Pemberian insentif harga susu segar bagi peternak yang telah memiliki self responsibility

a. Menyelenggarakan diklat pengolahan bahan pakan lokal secara reguler

b. Melakukan pendampingan penanganan bahan pakan lokal secara reguler

c. Pemberian insentif harga susu segar bagi peternak yang telah menggunakan bahan pakan lokal

a. Menyelenggarakan diklat pengolahan limbah kandang scara reguler

b. Melakukan pendampingan penanganan limbah kandang secara reguler

c. Pemberian insentif harga susu segar bagi peternak yang telah memanfaatkan limbah kandang

a. Menyelenggarakan leadership training dan benchmarking secara reguler

b. Pemberian insentif berbasis kinerja melalui instrumen kebijakan pemerintah

a. Pemberian insentif berbasis kinerja melalui instrumen kebijakan pemerintah

b. Pemberian insentif berbasis kinerja melalui instrumen kebijakan IPS

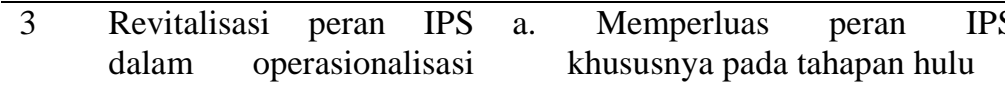
milk district model Nestlé

a. Pemberian fasilitas kredit lunak dalam pengadaan sapronak

b. Melakukan kegiatan technical assistances dalam pengadaan sapronak

b. Pengembangan usahaternak sapi a. Memfasilitasi terbentuknya cluster perah dengan pola cluster development partnership development partnership

b. Melakukan kegiatan technical assistances

c. Berperan sebagai avalist (penjamin) pengadaan sapi induk melalui kredit sektor perbankan

4 Revitalisasi peran pemerintah, instansi/dinas terkait, serta PT dan LSM dalam operasionalisasi milk district model Nestlé
a. Penyusunan instrumen kebijakan a. Pemberian insentif bagi peternak, dan program insentif koperasi dan IPS melalui keringanan pajak dan retribusi

b. Penyusunan instrumen pen- a. Melakukan berbagai jenis kegiatan dampingan pendampingan secara reguler
7) dirintis pengembangan usahaternak sapi perah dengan pola cluster development partnership melalui keterlibatan seluruh stakeholders, utamanya pihak IPS dan pemerintah, dan 8) disusun berbagai instrumen kebijakan dan program insentif serta pendampingan (technical assistances) agar pengembangan agri-bisnis sapi perah dapat lebih efisien dan memiliki daya saing.

\section{Daftar Pustaka}

Ashley, C. and K. Hussein. 2000. Working Paper 129: Developing Methodologies for Livelihood Impact Assessment, Livelihoods Support Programs Working Paper, FAO, Rome. 
Cleary, D., P. Baumann, M. Bruno, X. Flores, and P. Warren. 2003. People-Centred Approaches: A Brief Literature Review and Comparison of Types. Livelihoods Support Programme (LSP) Working Paper 5, June 2004. FAO. Rome.

Dispetprov, Jatim. 2006. Statistik Peternakan Jawa Timur 2005.

GKSI. 2000. Rencana Pembelian Sapi Perah Impor, 7000 Ekor. Korda Jawa Timur. Surabaya.

Johnson, C.A. 2000. Rules, Norms And The Pursuit Of Sustainable Livelihoods. Working Paper 52 of the Institute of Development Studies, London School of Economics. London.

Mavunduse, D., M. Nandango, S. Saadi, and E. de Leon. 2000. Participatory Vulnerability Analysis: A Step-By-Step Guide For Field
Staff. Emegencies Programme. Action Aids. UK.

Poulton, W. 2000. Partnerships for Sustainable Livelihoods : Doing Business with the Poor A Field Guide. WBCSD Sustainable Livelihoods Project, Eskom.

Singh, N. and J. Gilman. 2001. Employment and Natural Resurces Management: A Livelihoods Approach to Poverty Reduction, SEPED Conference Paper Series No.5.

Smith, D. and P. Riethmuller. 1995. The Indonesian Dairy Industry. Discussion Papers. Center for Agro-Socio Economic Research and The University of Queensland. Brisbane. Australia.

The Department for International Development. 1999. Sustainable Livelihoods: Guidance Sheets. Department For International Development, London. 